\title{
CHEMICAL COMPOSITION AND ANTIMICROBIAL ACTIVITY OF OREGANO (Lippia palmeri S. WATS) ESSENTIAL OIL
}

\section{COMPOSICIÓN QUÍMICA Y ACTIVIDAD ANTIMICROBIANA DEL ACEITE ESENCIAL DE ORÉGANO (Lippia palmeri S. WATS)}

\author{
Ma. Magdalena Ortega-Nieblas', Ma. Refugio Robles-Burgueño², Evelia Acedo-Félix ${ }^{2}$, \\ Alberto González-León ${ }^{2}$, Adriana Morales-Trejo ${ }^{3}$ and Luz Vázquez-Moreno ${ }^{2 *}$
}

\begin{abstract}
${ }^{1}$ Departamento de Investigaciones Científicas y Tecnológicas, Universidad de Sonora. Rosales y Blvd. Luis Encinas s/n, Edificio 7G. 1819, Hermosillo, Sonora, México. ${ }^{2}$ Centro de Investigación en Alimentación y Desarrollo A. C. Km 0.6 Carretera a La Victoria 83304, Apdo. postal 1735. Hermosillo, Sonora, México. Tel. 01 (662) 289-2400 Ext. 219 Fax: 01(662) 2800058. ${ }^{3}$ Instituto de Ciencias Agrícolas, Universidad Autónoma de Baja California. Carretera a Delta s/n 21705, Ejido Nuevo León, Baja California, México.
\end{abstract}

* Autor para correspondencia (lvazquez@ciad.mx)

\section{SUMMARY}

The chemical composition and antimicrobial activity of Lippia palmeri S. Wats essential oil extracted from plants collected of two localities (Álamos and Puerto del Orégano) in the State of Sonora, México, was examined. Essential oils (EO) were obtained from oregano leaves by steam distillation, analyzed by gas chromatography coupled with a mass spectrometer, and their antimicrobial activity against human pathogens investigated by disc diffusion. Álamos and Puerto del Orégano essential oils (AEO and POEO) presented 50 and 60 constituents, respectively. The components were classified as monoterpenes, sesquiterpenes and phenolics. AEO most abundant components $(>2 \%)$ included pcymene, thymol, isoaromandrene, carvacrol, $y$-terpinene, p-thymol, longipinene-epoxide and eudesmol; while for POEO were carvacrol, thymol, p-cymene, caryophyllene, thymol acetate, $\alpha$-bisabolene, $\gamma$ terpinene, myrcene and $\alpha$-caryophyllene. These results implicate that chemotypes involved were a p-cymene/thymol in AEO and carvacrol in POEO. In general, EO antimicrobial activity against four Gram-positive and six Gram-negative bacteria varied according to the plant origin. However, both POEO and AEO showed the strongest activity against Escherichia coli $0157: \mathrm{H} 7$ and Staphylococcus aureus. This is the first report of $L$. palmeri essential oil characterization, and our results support the notion that these oils could be useful in food flavoring and preservation.

Index words: Lippia palmeri, antimicrobial activity, essential oil composition, oregano Verbenaceae.

\section{RESUMEN}

Se estudió la composición química y la actividad antimicrobiana del aceite esencial de Lippia palmeri S. Wats, colectada en dos localidades del Estado de Sonora, México. Los aceites esenciales (AE) fueron obtenidos de las hojas del orégano por hidrodestilación, analizados por cromatografía de gases acoplada con espectrómetría de masas, y su actividad antimicrobiana fue investigada por difusión en disco. Los aceites esenciales de Álamos (AEA) y del Puerto del Orégano (AEPO) presentaron 50 y 60 constitu-yentes, respectivamente. Los componentes fueron clasificados como monoterpenos, sesquiterpenos y fenólicos. Los componentes más abundantes en AEA $(>2 \%)$ incluyeron p-cimeno, timol, isoaromandreno, carvacrol, $v$-terpineno, p-timol, longipinenoepóxido y eudesmol; mientras que para AEPO fueron carvacrol, timol, p-cimeno, cariofileno, acetato de timol, $\alpha$-bisaboleno, $\gamma$ terpineno, mirceno y $\alpha$-cariofileno. Estos resultados implican que los quimiotipos involucrados fueron: p-cimeno/timol en AEA, y carvacrol en AEPO. En general, la actividad antimicrobiana de los AE contra cuatro bacterias Gram-positivas y seis bacterias Gramnegativas varió con respecto al origen de la planta. Sin embargo, ambos AE mostraron mayor actividad contra Escherichia coli 0157:H7 y Staphylococcus aureus. Este es el primer reporte de la caracterización aceite del aceite esencial de $L$. palmeri, y estos resultados apoyan el concepto de que pueden ser utilizados para saborizar y preservar alimentos.

Palabras claves: Lippia palmeri, actividad antimicrobiana, composición del aceite esencial, orégano Verbenaceae.

\section{INTRODUCTION}

Lippia palmeri S. Wats (oregano) belongs to the Verbenaceae family. The oregano plant is a bushy, highly branched shrub from the semiarid zones of Sonora, Baja California and Sinaloa, México (Shreve and Wiggin, 1964). Essential oils (EO) of some Lippias species have characteristics comparable to European oregano, Origanum vulgare (González-Güereca et al., 2007), is used as flavoring power for food products and alcoholic beverages (Aligiannis et al., 2001; Silva-Vázquez and Dunford, 2005), and has also medicinal properties (Pascual et al., 2001). L. graveolens EO contains 45 chemical compounds and the main components are carvacrol, thymol, eugenol, cimene, pinene and linalool, among others (Vernin et al., 2001). Some of these components possess antibacterial, antiviral, antifungal and 
insecticidal properties (Carson and Riley, 1995; Botelho et al., 2007; Oyedemi et al., 2009). L. alba Mill and other Lippias have medicinal properties attributed to the high content of terpenes, that include limonene, myrcene, durene and p-cymene (Pascual et al., 2001).

Essential oil from many aromatic spices (oregano, thyme, salvia, parsley, clove, coriander, garlic and onion) show antimicrobial activity, that varies depending on species, sub-species and plant varieties (Friedman et al., 2002; Burt, 2004; Benkeblia, 2004; Celikel and Kavas, 2008; Martino et al., 2009).

Variability in amount and composition of essential oil in some plants, particularly in Origanium vulgare and Lippias depend on their developmental stage, climate factors, altitude, harvest season and plant handling (Kokkini et al., 1997; Dunford and Silva, 2005). Several reports show that the highest concentration occurs when leaves are harvested during the plant flowering stage. In México, most handling of the wild population of oregano is according to the Mexican Official Norm (Carabias, 1997).

The chemical composition and some biological activities of essential oils of several Lippias and Origanium species have been reported; however, this is not known for the Mexican Lippia palmeri. The aim of this work was to characterize and to determine the antimicrobial activity of the essential oil of Lippia palmeri S. Wats harvested from two different (a hot arid and temperate climate) locations in the State of Sonora, México.

\section{MATERIALS AND METHODS}

\section{Plant material}

Oregano leaves from Lippia palmeri S. Wats were obtained from Puerto del Orégano, a hot arid site, located at $52 \mathrm{~km}$ West of Hermosillo, Sonora, with geographical coordinates of $29^{\circ} 02^{\prime} 52.5^{\prime \prime} \mathrm{LN}$ and $110^{\circ} 40^{\prime} 15.8^{\prime \prime}$ $\mathrm{LW}$, at an altitude of $280 \mathrm{~m}$, with a maximum and minimum temperatures of 48 and $14{ }^{\circ} \mathrm{C}$, respectively, and an average annual precipitation of $180 \mathrm{~mm}$. The second location, Álamos, Sonora is a temperate site, with a mean precipitation of $347 \mathrm{~mm}$, altitude of $1700 \mathrm{~m}, 27^{\circ} 01^{\prime} 01^{\prime}$ $18^{\prime \prime} \mathrm{LN}$ and of $108^{\circ} 56^{\prime} 34^{\prime \prime} \mathrm{LW}$, with maximum and minimum temperatures of 30 and $16{ }^{\circ} \mathrm{C}$, respectively (INEGI, 2009). Plant collection was in October 2008, right before flowering. Samples were registered under voucher specimen No. 01655 at the Herbarium of the University of Sonora, where taxonomy was confirmed.

\section{Extraction and isolation}

Oregano leaves were dried at room temperature and shade, separated from stems and stored in paper bags. The moisture content was determined by weight difference and ash content as described by AOAC (2002).

Each batch of essential oils from Álamos and Puerto de Orégano (AEO and POEO, respectively), was obtained from $100 \mathrm{~g}$ of leaves by water steam distillation using a Clevenger type apparatus (Winzer ${ }^{\circledR}$ ), during $4 \mathrm{~h}$ with 1.5 $\mathrm{L}$ of distilled water. Essentials oils (EO) were separated from the aqueous phase using a separation funnel, dried over anhydrous sodium sulfate and stored at $4{ }^{\circ} \mathrm{C}$ until gas chromatography-mass spectrometry (GC-MS) analyses. EO content was expressed in $\mathrm{mL} 100 \mathrm{~g}^{-1}$ of dried leaves. Density or specific gravity was determined by the method described in AOAC (2002) using a pycnometer. Refraction index was obtained using a Bausch \& Lomb Abbe-31® refractometer, oil color determined using a Minolta colorimeter Chromameter CR200®, and free fatty acid content was determined by alkali titration according to method described in AOCS (2009). All determinations were done by triplicates.

\section{GC-MS analysis of Lippia palmeri essential oil}

AEO and POEO composition was analyzed by GC-MS using a gas chromatograph Varian $3900{ }^{\circledR}$ coupled to a Varian Saturn 2100T ${ }^{\circledR}$ ion trap mass spectrometer, DB5MS column (30 m x $0.25 \mathrm{~mm}$, film thickness $0.25 \mathrm{~mm}$ ). Operating conditions were as follows: Carrier gas used was ultra pure helium degree 5.0 at a flow rate of $1 \mathrm{~mL}$ $\mathrm{min}^{-1}$; column temperature was held constant at $50^{\circ} \mathrm{C}$ for $10 \mathrm{~min}$, then heated to $290{ }^{\circ} \mathrm{C}$ at $5{ }^{\circ} \mathrm{C} \mathrm{min}{ }^{-1}$ and held constant at $290{ }^{\circ} \mathrm{C}$ for $10 \mathrm{~min}$; injector temperature was $300{ }^{\circ} \mathrm{C}$; volume injected, $1 \mu \mathrm{L}$ of EO in methanol (1:10); split ratio, 1:100. The MS operating parameters were as follows: ionization potential, $70 \mathrm{eV}$; electronic ionization source temperature, $300{ }^{\circ} \mathrm{C}$; total ion monitoring was done in a scan mass range from $40-400 \mathrm{~m} / \mathrm{z}$ (D'antuono et $a l ., 2000)$. The identification of GC peaks corresponding to the components of the EO was based on direct comparison of the retention times and mass spectra data with those standards compounds when available, computing matching with the NIST 2000 library, and by comparison of the fragmentation patterns of the mass spectra with those reported in the literature (Pino et al., 1997; Derwich et al., 2010). Relative percentage amounts of separated compound were calculated from peak areas of the total ion chromatograms. 


\section{Antimicrobial activity}

Microorganisms tested were obtained from the collection of the accredited microbiology laboratory at Centro de Investigación en Alimentación y Desarrollo, A. C. (Hermosillo, Sonora. México). Antibacterial activity of EOs against Gram-positive bacteria (Staphylococcus aureus, Staphylococcus epidermidis, Listeria ivanovii and Listeria monocytogenes) and Gram-negative bacteria (Salmonella Senftemberg, Salmonella Choleraesuis, Salmonella Typhimurium, Escherichia coli K88, Escherichia coli O157:H7 and Escherichia coli ATCC25922) was determined using a modified technique (paper disc diffusion method) described by Prabuseenivasan et al., (2006). Briefly, bacteria grown in Mueller-Hinton broth at $37{ }^{\circ} \mathrm{C}$ for $18 \mathrm{~h}$ was adjusted to $10^{5} \mathrm{UFC} \mathrm{mL}^{-1}$ with sterile saline solution and streaked on agar plate using sterile cotton swabs for a uniform lawn growth. Essential oils were diluted with $10 \%$ dimethylsulfoxide (DMSO) containing $0.5 \%$ Tween ${ }^{\circledR} 80$ $(\mathrm{v} / \mathrm{v})$ and sterilized by filtration through a $0.45 \mu \mathrm{m}$ membrane filter. Oil dilutions tested were 1:1 (6.6 $\mathrm{mg} /$ disc $), \quad 1: 5(2.6 \mathrm{mg} / \mathrm{disc})$ and $1: 10(1.3 \mathrm{mg} / \mathrm{disc})$. Fifteen microliters of each dilution of essential oils were loaded on sterile filter paper discs $(5 \mathrm{~mm}$ in diameter, Whatman ${ }^{\circledR}$ No. 1) allowed to dry in an open sterile petri dish and applied on top of agar plates. Plates were left for $30 \mathrm{~min}$ at room temperature and then incubated at $37{ }^{\circ} \mathrm{C}$ for 18-24 h. After incubation, growth inhibition halos were recorded. Tests were carried out in duplicate and mean value calculated. Controls included discs impregnated with $15 \mu \mathrm{L}$ of DMSO (as vehicle control) and streptomycin $(25 \mu \mathrm{g} / \mathrm{disc})$.

The sensibility to each of oil was classified according to growth inhibition diameter and to specifications described by Celikel and Kavas (2008): not sensitive, if the total diameter was under $8.0 \mathrm{~mm}$; sensitive for $9-14 \mathrm{~mm}$; highly sensitive for $15-19 \mathrm{~mm}$; and extremely sensitive to inhibition for diameters larger than $20 \mathrm{~mm}$.

\section{Statistical analysis}

In order to establish possible differences in the physical chemical characteristics of Lippia palmeri essential oils, a variance analysis was performed with a significance level $\alpha=0.05$, and mean comparison was done by the Tukey's test, using the JMP package version 5.0.1 (SAS Institute, 2002).

For antimicrobial activity, the experimental design was a completely randomized with factorial arrangement of $2 \times 3$, where factor A was essential oil with two levels (AEO and POEO), and factor B were dilutions with three levels (1:1, 1:5 and 1:10 dilutions). Data were analyzed by ANOVA/GLM at $\mathrm{P}<0.05$. Mean comparison was done by Tukey-Kramer multiple-comparison test using the NCSS package (2001).

\section{RESULTS AND DISCUSSION}

Yield and some physical-chemical characteristics of oregano EO from both localities are shown in Table 1. Puerto del Orégano plants had $6 \%$ of essential oil yield, while Álamos plants contained $5 \%$. Oreganum vulgare oil, L. sidoides and Lippia julliana have similar yields (Juliani et al., 2002; Nunes et al., 2005; Wogiatzi et al., 2009). These percentages were higher than those reported for L. multiflora $(0.16 \%), L$. alba $(0.6 \%)$, L. graveolens (3.5\%), and L. laxibracteata (3 \%) (Juliani et al., 2000; Salgueiro et al., 2003; Gómez et al., 2007; Owolabi et al., 2009). The moisture content of POEO was significantly lower than AEO, due to the fact that POEO comes from a most arid habitat. No significant differences $(\mathrm{P}<0.05)$ were found in EO refractive index $(\mathrm{RI})$, density or specific weight, free acidity and color. RI for POEO and AEO were 1.4813 and 1.4770, respectively, values which are slightly lower than those reported (1.4817-1.4918) for L. alba (Ricciardi and Ricciardi, 2000) and for L. graveolens (Analiz et al., 2000) and $O$. vulgare (Albado et al., 2001). The studied EO exhibited slightly lower density than those from Origanum and other Lippia species (Ricciardi and Ricciardi, 2000; Analiz et al., 2000; Albado et al., 2001).

Table 1. Characteristics of Lippia palmeri essential oil from two locations of the State of Sonora, México.

\begin{tabular}{lll}
\hline Characteristics & AEO & POEO \\
\hline Essential oil yield (\%) & $5.00 \mathrm{a}$ & $6.00 \mathrm{~b}$ \\
Humidity (\%) & $7.12 \mathrm{~b}$ & $3.15 \mathrm{a}$ \\
Ashes $(\%)$ & $7.58 \mathrm{~b}$ & $8.43 \mathrm{a}$ \\
Refraction index at $25{ }^{\circ} \mathrm{C}$ & $1.47 \mathrm{a}$ & $1.48 \mathrm{a}$ \\
Specific density $\left(\mathrm{g} \mathrm{mL}^{-1}\right)$ & $0.88 \mathrm{a}$ & $0.87 \mathrm{a}$ \\
Free acidity index $(\%)$ & $2.80 \mathrm{a}$ & $2.30 \mathrm{a}$ \\
Color & $2.4 \mathrm{R} \mathrm{50A} \mathrm{a}$ & $2.4 \mathrm{R} \mathrm{50A} \mathrm{a}$ \\
& Yellow & Yellow \\
\hline
\end{tabular}

Means $(n=3)$ with the same letter in a row indicate there are not significant differences (Tukey, 0.05). AEO = Álamos essential oil; POEO $=$ Puerto del Orégano essential oil.

Analysis of EO by GC-MS led to the identification and quantification of a total of 50 compounds AEO while for POEO presented 60 compounds, accounting for 99.9 and $99.6 \%$ of total components (Table 2). Identification was done by direct comparison of the retention times and mass spectral data of compounds with their respective reference compounds, library matching and by comparison of the fragmentation patterns of mass spectra with reports in the literature. The identification of the compound is fairly strong since was done by recording total ion count and not 
by selected ions $(\mathrm{m} / \mathrm{z})$, with chromatograms reported by NIST library. In AEO, 11 components were the most abundant (1.0-22.3\%) and constituted $90.4 \%$ of the oil. These components included p-cymene $(22.3 \%)$, followed by thymol $(21.3 \%)$, iso-aromandrene $(16.7 \%)$, carvacrol $(8.8 \%), \quad \gamma$-terpinene $(6.7 \%)$, p-thymol $(5.9 \%)$, longipinene epoxide $(2.6 \%)$, $\alpha$-eudesmol $(2.5 \%), \alpha$ bisabolene epoxide $(1.3 \%)$ and limonene-6-ol $(1.2 \%)$.
In POEO, 12 compounds were the most abundant (1.1$24.5 \%$ ) representing $88.1 \%$ of total oils, which included carvacrol $(24.5 \%)$, thymol (15.1\%), p-cymene $(14.2$ $\%)$, caryophyllene $(9.9 \%)$, thymol acetate $(5.5 \%), \alpha-$ bisabolene $(4.8 \%), \gamma$-terpinene $(4.2 \%)$, myrcene $(3.8$ $\%)$, $\alpha$-caryophyllene $(2.2 \%)$, linalool $(1.2 \%)$, and terpinene-4-ol (1.1\%).

Table 2. Constituents of leaves Lippia palmeri essential oil from two localities in the State of Sonora, México, analyzed by gas chromatography - mass spectrometry.

\begin{tabular}{|c|c|c|c|c|c|}
\hline \multirow{2}{*}{$\begin{array}{r}\mathrm{RT}^{\dagger} \\
(\mathrm{min})\end{array}$} & \multirow[t]{2}{*}{ Compounds } & \multicolumn{2}{|c|}{ Amount in oil (\%) } & \multirow{2}{*}{$\begin{array}{c}\text { Molecular } \\
\text { ion }(\mathrm{m} / \mathrm{z})\end{array}$} & \multirow{2}{*}{$\begin{array}{l}{ }^{\dagger+\dagger} \text { Main fragment ions } \\
(\mathrm{m} / \mathrm{z})\end{array}$} \\
\hline & & $\mathrm{AEO}^{\dagger \dagger}$ & $\mathrm{POEO}^{\dagger \dagger \dagger}$ & & \\
\hline 3.69 & 2-Ethyl-furan & 0.02 & 0.02 & 96 & $55,67,42,89$ \\
\hline 4.37 & Prenal & 0.17 & 0.03 & 84 & $83,55,67,42$ \\
\hline 5.59 & Borneol & 0.07 & 0.34 & 154 & $67,95,81,55,110,93$ \\
\hline 7.60 & 2-Methoxy diethylamine & nd & 0.12 & 103 & $99,67,41,115,69,55$ \\
\hline 10.60 & $\beta$-Pinene & 0.12 & 0.22 & 136 & $93,79,41,105,68$ \\
\hline 11.06 & $\alpha$-Thujene & 0.07 & 0.31 & 136 & $91,93,79,77,41,51$ \\
\hline 11.46 & $\alpha$-Pinene & 0.32 & 0.23 & 136 & $93,91,77,92,79$ \\
\hline 12.16 & Origanene & 0.22 & 0.13 & 152 & $94,92,77,91,55,103$ \\
\hline 12.43 & $\alpha$-Terpinolene & 0.24 & 0.18 & 136 & $93,122,105,121,79.77$ \\
\hline 13.70 & o-Cymene & 0.23 & 0.22 & 134 & $77,119,115,41$ \\
\hline 13.81 & 3-Carene & 0.34 & 0.01 & 136 & $91,79,113,77,122,80$ \\
\hline 14.01 & $\beta$-Phellandrene & 0.01 & 0.08 & 136 & $93,91,77,41,50,135$ \\
\hline 14.46 & 1-Nonen 3-ol & 0.33 & 0.24 & 142 & $57,43,41,55,88,105$ \\
\hline 14.61 & 2-Ethyl-oxole & nd & 0.03 & 128 & $57,43,41,108,67,55$ \\
\hline 14.82 & Myrcene & 0.16 & 3.82 & 136 & $93,41,69,91,67,79$ \\
\hline 15.30 & 3-Octanol & 0.08 & 0.02 & 130 & $119,116,99,43$ \\
\hline 15.52 & $\alpha$-Phellandrene & 0.14 & 0.03 & 136 & $91,93,77,92,51$ \\
\hline 15.60 & $\alpha$-Terpinene & 0.30 & 0.13 & 136 & $93,91,77,40,79,103$ \\
\hline 16.03 & Terpinolene & 0.06 & 0.18 & 136 & $93,121,136,77,39,79$ \\
\hline 16.19 & Cymene & 0.03 & 0.05 & 134 & $119,134,91,94,65,121$ \\
\hline 16.50 & p-Cymene & 22.37 & 14.25 & 134 & $91,119,67,65,41$ \\
\hline 16.63 & Limonene & nd & 0.74 & 136 & $68,119,93,91,67,79$ \\
\hline 16.72 & Caryophyllene oxide & 0.81 & nd & 220 & $41,79,43,69,94,81$ \\
\hline 17.88 & $\mathrm{t}$-Terpinene & nd & 0.13 & 136 & $93,91,77,136,121,92$ \\
\hline 18.44 & Cis-b-Terpineol & nd & 0.10 & 154 & $43,93,121,71,79,81$ \\
\hline 19.21 & Dehydro-p-Cymene & nd & 0.07 & 132 & $118,115,91,65,131$ \\
\hline 19.29 & Durenol & 0.27 & 0.16 & 150 & $117,132,115,91,50,82$ \\
\hline 19.68 & Linalool & 0.44 & 1.20 & 136 & $93,71,55,41,69,77$ \\
\hline 19.91 & $\alpha$-Bisabolene epoxide & 1.31 & 0.11 & 220 & $71,43,93,121,69$ \\
\hline 20.43 & 3-Allyl cyclohexene & nd & 0.02 & 122 & $81,78,77,53,41$ \\
\hline 20.96 & Phellandrene & nd & 0.05 & 136 & $77,91,136,79,94,80$ \\
\hline 21.95 & 2-Pinene 4-one & 0.1 & 0.04 & 159 & $93,41,79,57,137$ \\
\hline 22.08 & 3-Thujene 2-one & 0.09 & 0.24 & 150 & $95,67,41,55,77,91$ \\
\hline 22.51 & Terpinene 4-ol & 0.37 & 1.15 & 154 & $71,93,43,68,55,88$ \\
\hline 22.79 & p-Cymene 8-ol & 0.08 & 0.04 & 150 & $135,119,91,65,55$ \\
\hline 23.01 & $\alpha$-Terpineol & 0.12 & 0.19 & 154 & $59,43,121,93,91,136$ \\
\hline 24.03 & Thymol methylether & 0.27 & 0.12 & 164 & $150,91,43,71,41$ \\
\hline 24.40 & $\alpha$-Pinene epoxide & nd & 0.50 & 152 & $41,93,69,93,121$ \\
\hline 24.64 & Linalool acetate & 0.12 & nd & 136 & $93,43,41,91,121,79$ \\
\hline 24.91 & Geraniol & 0.45 & 0.52 & 154 & $81,41,68,43,44,70$ \\
\hline 25.81 & Carvacrol & 8.76 & 24.57 & 150 & $135,107,91,51,43$ \\
\hline 26.15 & Thymol acetate & nd & 5.5 & 192 & $135,150,107,91,63$ \\
\hline 26.34 & Thymol & 21.39 & 15.11 & 150 & $135,107,151,43,91$ \\
\hline 26.43 & p-Thymol & 5.94 & nd & 150 & $135,107,91,43,151$ \\
\hline 27.71 & Eugenol & nd & 1.34 & 164 & $149,103,77,55,121$ \\
\hline
\end{tabular}


Table 2 (continued).

\begin{tabular}{llccll}
\hline 28.00 & o-Cymene 5-ol & 0.19 & nd & 150 & $119,150,91,107,134$ \\
28.34 & Geraniol acetate & nd & 0.49 & 196 & $69,41,43,67,93,121$ \\
28.98 & Methyl eugenol & nd & 0.80 & 178 & $164,149,91,103,55$ \\
29.50 & b-Caryophyllene & 0.08 & 9.96 & 204 & $93,69,134,91,41,105$ \\
29.79 & b-Farnesene & 0.24 & 0.06 & 204 & $41,69,93,42,77,133$ \\
29.98 & Aromandrene & 0.21 & 0.41 & 204 & $161,91,105,119,107,41$ \\
30.43 & $\alpha$-Caryophyllene & nd & 2.24 & 204 & $93,151,91,105,79,77$ \\
31.13 & $\gamma$-Terpinene & 6.69 & 4.23 & 136 & $93,121,78,105,91,43$ \\
31.34 & Longifolene & nd & 0.07 & 204 & $165,104,107,151,91,93$ \\
31.71 & b-Bisabolene & 1.04 & 0.44 & 204 & $93,121,165,105,91,43$ \\
33.49 & (-) Spathulenol & 0.83 & 0.85 & 204 & $43,159,105,131,93,187$ \\
33.62 & $\alpha-B i s a b o l e n e$ & 0.39 & 4.77 & 204 & $95,107,121,109,105,43$ \\
34.25 & iso-Caryophyllene & nd & 0.52 & 222 & $67,93,107,79,91,205$ \\
34.58 & b-Eudesmol & 0.13 & 0.15 & 222 & $149,93,108,67,79,81$ \\
34.90 & Alloaromandrene & 0.41 & 0.41 & 220 & $136,91,41,67,77,93$ \\
35.36 & $\alpha$-Eudesmol & 2.49 & 0.91 & 222 & $67,41,93,77,81,91$ \\
35.70 & iso-Aromandrene & 16.7 & 0.62 & 222 & $91,93,107,41,105,77$ \\
39.38 & Longipinene epoxide & 2.58 & nd & 252 & $43,95,109,58,77,81$ \\
40.27 & 4-Carene & 0.16 & 0.07 & 136 & $113,91,121,81,77,135$ \\
42.86 & m-Cymene & 0.81 & nd & 134 & $135,91,121,79,150,119$ \\
43.01 & Limonen 6-ol & 1.22 & 0.08 & 236 & $93,67,109,68,177,50$ \\
& Total identified & $\mathbf{9 9 . 9 4}$ & $\mathbf{9 9 . 6 3}$ & & \\
\hline
\end{tabular}

${ }^{\dagger} \mathrm{RT}=$ retention time; nd $=$ not detected ${ }^{\dagger} \mathrm{AEO}=$ Álamos essential oil; ${ }^{\dagger \dagger} \mathrm{POEO}=$ Puerto del Orégano essential oil. Composition was analyzed by a gas chromatograph Varian 3900 coupled to a Varian Saturn 2100T ion trap mass spectrometer; ${ }^{\dagger \dagger}$ Molecular and fragment ions $(\mathrm{m} / \mathrm{z})$ were determined by mass spectrometry, electronic ion ionization at 70 $\mathrm{eV}$, total ion monitoring was done in a scan mass range from $40-400 \mathrm{~m} / \mathrm{z}$, and match comparison with the NIST-MS library.

The essential oil from both plant sources appeared quite different and allowed to identify two chemotypes: AEO as a p-cymene/thymol and POEO as a carvacrol chemotype. Similar chemical polymorphism has been reported for $O$. vulgaris L. ssp hirtum (Martino et al., 2009; Kokkini et al., 1997), O. syriacum L. (Lukas et al., 2009) and Lippia junelliana (Juliani et al., 2002).

When compounds of both EO were grouped by their chemical functionality, the major group corresponded to phenolic monoterpenes, followed by monoterpenes hydrocarbons and sesquiterpene hydrocarbons (Table 3). Total monoterpenes in AEO was $72.3 \%$ and $75.6 \%$ for POEO, while sesquiterpenes accounted 27.2 and $21.5 \%$, respectively. Monoterpenes and sesquiterpenes represented 99.4 and $97.1 \%$ of the total component for the studied EO of both localities. These results make evident the composition dependency of essential oils with the geographical origin of Lippia genus (Prabuseenivasan et al., 2006; Owolabi et al., 2009).

In vitro studies have demonstrated antibacterial activity of spices and Lippia essential oils against some Gramnegative and Gram-positive bacteria (Salgueiro et al., 2003; Burt, 2004; Botelho et al., 2007; Gómez et al., 2007; Paredes et al., 2007; Owolabi et al., 2009). Some species of Lippia EO are commonly used in folk medicine, as gastrointestinal and respiratory remedies, and for treatment of skin wounds. Their biological properties have been attributed to the content of carvacrol, thymol and p-cymene (Burt, 2004).

Table 3: Grouped components of essential from Lippia palmeri leaves, based on their chemical functionality.

\begin{tabular}{lll}
\hline \multirow{2}{*}{ Constituents } & \multicolumn{2}{c}{ Percentage in essential oil } \\
\cline { 2 - 3 } Monoterpene hydrocarbons & 32.26 & POEO \\
Oxygenated monoterpenes & 3.64 & 25.06 \\
Phenolic monoterpenes & 36.36 & 5.23 \\
Sesquiterpene hydrocarbons & 19.06 & 45.29 \\
Oxygenated sesquiterpenes & 8.16 & 19.50 \\
Phenolics & 0.26 & 2.03 \\
Others & 0.19 & 2.30 \\
Total identified & $\mathbf{9 9 . 9 4}$ & 0.22 \\
\hline AEO = Álamos essential oil; POEO = Puerto del Orégano essential oil.
\end{tabular}

The antimicrobial activity of $L$. palmeri essentials oils was tested against Gram negative and Gram positive human pathogens (except for S. epidermidis). All of them cause diseases transmitted by food or food intoxications. According to growth inhibition, bacteria were classified from not sensitive to extremely sensitive (Table 4). Results revealed that the inhibition of POEO was stronger than that of AEO. All microorganisms were extremely sensitive to $\mathrm{EO}$ at the highest concentration; at other concentrations, the antimicrobial effect varied (Listeria monocytogenes was not sensitive with POEO at the 1:10 dilution). 
Table 4. Halos of inhibition of bacterial growth caused by Lippia palmeri essential oils.

\begin{tabular}{|c|c|c|c|c|c|c|}
\hline \multirow[b]{3}{*}{ Bacteria } & \multicolumn{6}{|c|}{ Dilutions (mg/disc) } \\
\hline & $1: 1(6.6)$ & $1: 5(2.6)$ & $1: 10(1.3)$ & $1: 1(6.6)$ & $1: 5(2.6)$ & $1: 10(1.3)$ \\
\hline & \multicolumn{6}{|c|}{ Inhibition zones (mm) } \\
\hline Staphylococcus aureus ATCC $25923^{+,+,+\dagger \dagger}$ & $30.0 \pm 2.1 \mathrm{~b}$ & $19.5 \pm 0.7 \mathrm{c}$ & $20.5 \pm 0.7 \mathrm{c}$ & $37.0 \pm 0.0 \mathrm{a}$ & $28.0 \pm 1.4 \mathrm{~b}$ & $21.0 \pm 1.4 \mathrm{c}$ \\
\hline Staphylococcus epidermidis ATCC $2228^{\dagger, \dagger \dagger \dagger}$ & $30.0 \pm 0.0 \mathrm{~b}$ & $23.5 \pm 2.1 \mathrm{c}$ & $14.0 \pm 0.7 \mathrm{~d}$ & $38.0 \pm 0.0 \mathrm{a}$ & $29.0 \pm 1.4 \mathrm{~b}$ & $21.0 \pm 1.4 \mathrm{c}$ \\
\hline Listeria ivanovii ATCC $19119^{\dagger, \dagger,+\dagger \dagger}$ & $21.5 \pm 2.1 \mathrm{a}$ & $13.0 \pm 0.7 \mathrm{~b}$ & $10.5 \pm 0.7 \mathrm{~b}$ & $26.0 \pm 1.4 \mathrm{a}$ & $21.0 \pm 1.4 \mathrm{a}$ & $10.5 \pm 1.4 \mathrm{~b}$ \\
\hline Listeria monocytogenes ATCC $7644^{\dagger,+\dagger,+\dagger \dagger}$ & $24.0 \pm 1.4 \mathrm{a}$ & $9.5 \pm 0.7 \mathrm{c}$ & $9.0 \pm 0.0 \mathrm{c}$ & $20.0 \pm 0.0 \mathrm{~b}$ & $10.0 \pm 0.0 \mathrm{c}$ & $0.0 \pm 0.0 \mathrm{~d}$ \\
\hline Salmonella typhimurium ATCC $14028^{+, \dagger+, \dagger \dagger}$ & $22.5 \pm 0.7 \mathrm{a}$ & $20.5 \pm 0.7 \mathrm{a}$ & $12.5 \pm 0.7 \mathrm{~b}$ & $23.0 \pm 0.0 \mathrm{a}$ & $14.0 \pm 1.4 \mathrm{~b}$ & $12.5 \pm 1.4 \mathrm{~b}$ \\
\hline Escherichia coli $\mathrm{K} 88^{+, \dagger+, \dagger \dagger}$ & $26.0 \pm 0.0 \mathrm{a}$ & $11.5 \pm 0.7 \mathrm{c}$ & $13.0 \pm 1.4 \mathrm{c}$ & $29.0 \pm 0.3 \mathrm{a}$ & $18.5 \pm 1.4 \mathrm{~b}$ & $11.0 \pm 0.0 \mathrm{c}$ \\
\hline Escherichia coli $\mathrm{O} 157: \mathrm{H} 7^{\dagger+, \dagger \dagger}$ & $25.0 \pm 1.1 \mathrm{ab}$ & $23.5 \pm 0.7 \mathrm{~b}$ & $19.0 \pm 1.4 \mathrm{bc}$ & $30.0 \pm 0.0 \mathrm{a}$ & $21.0 \pm 2.8 \mathrm{~b}$ & $14.0 \pm 2.1 \mathrm{c}$ \\
\hline Escherichia coli ATCC $25922^{\dagger \dagger \dagger}$ & $25.0 \pm 0.0 \mathrm{a}$ & $19.0 \pm 2.1 \mathrm{~b}$ & $12.5 \pm 0.7 \mathrm{c}$ & $25.0 \pm 0.0 \mathrm{a}$ & $20.0 \pm 3.2 \mathrm{~b}$ & $12.0 \pm 0.0 \mathrm{c}$ \\
\hline
\end{tabular}

Numbers are means and standard deviations of diameter halos in millimeters (duplicates). AEO = Álamos essential oil; POEO = Puerto del Orégano essential oil. ${ }^{\dagger}$ Significant differences between Eos; ${ }^{\dagger \dagger}$ Significant interactions. ${ }^{\dagger \dagger}$ Significant differences between dilutions (Tukey, 0.05). Means with the same letter in a row indicate that there are not significant differences (Tukey, 0.05). Bacteria sensibility clasification by Celikel and Kavas (2008). Not sensitive $=$ halo of inhibition $<8.0 \mathrm{~mm}$; sensitive $=9-14 \mathrm{~mm}$; highly sensitive $=15-19 \mathrm{~mm}$; and extremely sensitive, $>20 \mathrm{~mm}$.

Differences were significant only for $S$. aureus, $S$. epidermidis, L. inovani, L. monocytogenes, $\mathrm{S}$. typhimurium and E. coli K88. Interactions (EO and dilutions) were significant in all bacteria except for $S$. epidermidis, S. senftemberg, S. Choleraesuis and E.coli ATCC 25922. (Table 4). These results showed that antimicrobial activity against $S$. aureus, $L$. inovani, $L$. monocytogenes, $S$. typhimurium E. coli K88 and E. coli O157:H7 decrease with reduction of EO concentration. The observed reduced response of $L$. monocytogenes has also been reported for EO obtained from thyme, sage, myrtle, orange and laurel (Celikel and Kavas, 2008).

It is important to emphasize that Escherichia coli O157:H7 and Staphylococcus aureus are two of the pathogen of greatest concern in the industry of meat products, in which $L$. palmeri EO could be used as natural preservative.

In this study the variability of antimicrobial activity could be attributed to differences in composition of oregano oil, and in bacterial target sites. The strong antimicrobial activity of POEO (compared to AEO) might be linked to its higher phenolic monoterpene content, and to thymol acetate, eugenol and methyl eugenol concentration. Other reports have attributed the antimicrobial effectiveness of oregano essential oils to thymol, eugenol and carvacrol (Analiz et al., 2000; Aligiannis et al., 2001; Salgueiro et al., 2003; Gómez et $a l ., 2007)$. The mechanism of action of these compounds was related to the hydrophobicity of EO components that enable them to break down the lipids of bacterial cell membranes, then increasing ion permeability, and lipid and protein leakage, which in turn could cause cell lysis (Aligiannis et al., 2001; Oyedemi et al., 2009).

\section{CONCLUSIONS}

The composition of essential oil from Lippia palmeri S. Wats varies the region of collection. AEO from a temperate zone was a p-cymene/thymol chemotype, while POEO from a most arid region was a carvacrol chemotype. Phenolic monoterpenes were the most abundant terpene group in both oils. With different potency, the oils studied have the ability to inhibit bacterial growth of pathogens, making L. palmeri essential oils useful for the food industry as flavoring agent and natural preservative.

\section{ACKNOWLEDGMENT}

Authors would like to recognize Rosalba Perez-Morales for technical support at the Microbiology Laboratory of CIAD.

\section{BIBLIOGRAPHY}

Albado P E, F Saez, G Ataucusi (2001) Composición química y actividad antibacteriana del aceite esencial del Origanum vulgare (Orégano). Rev. Méd. Hered. 12:16-19.

Analiz G L, F R Castro, L F Gómez (2000) Contribución al estudio de la calidad del aceite esencial de orégano (Lippia graveolens). Rev. Chapingo S. Z. Áridas 1:324-332.

Aligiannis N, E Kalpoutzakis, S Mitaku, IB Chinou (2001) Composition and antimicrobial activity of the essential oils of two Origanum species. J. Agric. Food Chem. 49:4168-4170.

AOAC, Association of Official Analytical Chemists (2002) Official Methods of Analysis. 17th ed. Washington, USA. pp:13-26.

AOCS, American Oils Chemists Society (2009) Official methods and recommended practices of American Oils Chemists Society. Vol 1, 6th ed. Champaign, Illinois, USA, AOCS Press. 1278 p.

Benkeblia N (2004) Antimicrobial activity of essential oil extracts of various onions (Allium cepa) and garlic (Allium sativum). Lebensmittel-Wissenschaft und-Technologie 37:263-268.

Botelho MA, N A P Nogueira, G M Bastos, S G C Fonseca, T L G Lemos, F J A Matos, D Montenegro, J Heukelbach, V S 
Rao, G A C Brito (2007) Antimicrobial activity of the essential oil from Lippia sidoides, carvacrol and thymol against oral pathogens. Braz. J. Medical Biol. Res. 40:349-356.

Burt S (2004) Essential oils: their antibacterial properties and potentials applications in foods- a review. Interntl. J. Food Microbiol. 94:223-253.

Carabias J (1997) Norma Oficial Mexicana NOM-007-RECNAT-1997.

Carson C F, T V Riley (1995) Antimicrobial activity of the major component of the essential oil of Melaleuca alternifolia. J. Appl. Bacteriol. 78:264-289.

Celikel N, G Kavas (2008) Antimicrobial properties of some essential oils against some pathogenic microorganisms. Czech J. Food Sci. 26:174-181.

D'antuono L F, G C Galleti, P Bocchini (2000) Variability of essential oil content and composition of Origanum vulgare L. populations from a North meditarranean area (Liguria region, Northern Italy). Ann. Bot. 86:471-478.

Derwich E, Z Benziane, A Boukir (2010) Chemical composition of leaf essential oil of Juniperus phoeniceae and evaluation of its antibacterial activity. Internati. J. Agric. Biol. 12:199-214.

Dunford N T, V R Silva (2005) Effect of water stress on plant growth and thymol and carvacrol concentration in Mexican oregano grown under controlled conditions. J. Appl. Horti. 7:20-22

Friedman M, Philip R H, R E Mandrell (2002) Bactericidal activities of plant essential oils and some of their isolates constituents against Campylobacter jejuni, Escherichia coli, Listeria monocytogenes, and Salmanella enterica. J. Food Protec. 65: $1545-1560$

Gómez G A, G D C Durán, J R Martínez, E E Stashenko, V J Olivero (2007) Comparación de la composición química y de la actividad biológica de los aceites esenciales de Lippia alba (Mill). Sci. Technol. 33:227-229.

González-Güereca M C, M Soto-Hernández, G Kite, M MartínezVázquez (2007) Antioxidant activity of flavonoids from the stem of the mexican oregano (Lippia graveolens HBK var. berlandieri Schauer). Rev. Fitotec. Mex. 30:43-49.

INEGI, Instituto Nacional de Estadística, Geografía e Informática (2009) Anuario Estad. Sonora 1:12-13.

Juliani H R Jr, F Biurrun, A R Koroch, H R Juliani, J A Zygadlo (2000) Chemical constituents of essential oil of Lippia laxibracteata (Vervenaceae). Planta Medica 66:567-568.

Juliani H R Jr, A R Koroch, H R Juliani, V S Trippi, J A Zygadlo (2002) Intraespecific variation in leaf oils of Lippia junelliana (mold) tronc. Biochem. Syst. Ecol. 30:163-170.

Kokkini S, R Karousou, A Dardiotti, N Krigas, T Lanaras (1997) Autumn essential oils of greek oregano. Phytochemistry 44:883-886.

Lukas B, C Schmiderer, C Franz, J Novak (2009) Composition of essential oil compounds from different Syrian populations of Origanum syriacum L. (Lamiaceae). J. Agric. Food Chem. $57: 1362-1365$
NCSS (2001) Number Cruncher Statistical System. Version 6.0.2. USA.

Martino L, V Feo, C Formisano, E Mignola, F Senatore (2009) Chemical composition and antimicrobial activity of the essential oils from three chemotypes of Origanum vulgare L. ssp. hirtum (Link) Ietswaart growing wild in Campania (Southern Italy). Molecules 14:2735-2746.

Nunes R S, A M Lira, E Ximenes, J A Silva, D P Santana (2005) Characterization of the Lippia sidoides in vegetable raw material for pharmaceutical products. Sci. Plena 1:182-184.

Owolabi M S, A Ogundajo, L Lajide, M O Oladimeji, W N Setzer, M C Palazzo (2009) Chemical composition and antibacterial activity of the essential oil of Lippia multiflora Moldenke from Nigeria. Rec. Natural Prod. 3:170-177.

Oyedemi S O, A I Okoh, LV Mabinya, G Pirochenva, A J Afolayan (2009) The proposed mechanism of bactericidal action of eugenol, $\quad \gamma$-terpineol and $\gamma$-terpinene against Listeria monocytogenes, Streptococcus pyogenes, Proteus vulgaris and Escherichia coli. African J. Biotechnol. 8:1280-1286.

Paredes A M C, F M G Gastélum, V R Silva (2007) Efecto antimicrobiano de orégano mexicano (Lippia berlandieri Schauer) y de su aceite esencial sobre cinco especies del género vibrio. Rev. Fitotec. Mex. 30:261-267.

Pascual M E, K Slowing, E Carretero, D Sánchez Mata, A Villar (2001) Lippia: traditional uses, chemistry and pharmacology: a review. J. Ethnopharmacol. 76:201-214.

Pino J A, A G Ortega, A R Perez, M Rodríguez, R Baduja (1997) Composición y propiedades antibacterianas del aceite esencial de Lippia alba (Mill) n.e. Brown. Rev. Cub. Farmacol. 30:1.

Prabuseenivasan S, M Jayakumar, S Ignacimuthu (2006) In vitro antibacterial activity of some plant essential oils. BMC Compl. Alternat. Med. 6:39-46.

Ricciardi G A, A Ricciardi (2000) Effect of stational variation and composition chemistry oil essential plant Lippia alba (Mill). J. Food Sci. 66:174-181

Salgueiro L, M Cavaleiro, A Goncalves, C Proenca (2003) Antimicrobial activity and chemical composition of essential oil of Lippia graveolens from Guatemala. Planta Medica 69:80-83.

Shreve F, I L Wiggin (1964) Vegetation and Flora of the Sonoran Desert. Vol. 2. Stanford University Press. USA. 1255 p.

Silva-Vázquez R, N T Dunford (2005) Bioactive components of Mexican oregano oil as affected by moisture and plant maturity. J. Essential Oil Res. 17:668-671.

Vernin G, C Lageot, E M Gaydou, C Parkanyi (2001) Analysis of essential oil of Lippia graveolens HBK from El Salvador. Flavour Fragance J. 16:219-226.

Wogiatzi E, N Gougoulias, A Papachatzis, I Vagelas, N Chouliaras (2009) Chemical composition and antimicrobial effects of Greek origanum species essential oil. Biotech. Biotech. Equipm. 23:1322-1324 